\title{
HUBUNGAN PELATIHAN BERCERITA TERHADAP KEMAMPUAN GURU DALAM BERCERITA DI TAMAN KANAK-KANAK
}

\author{
Rahmah \\ e-mail: rahmah_ukm@yahoo.com \\ STKIP Aisyiyah Riau \\ JL. Angkasa, No. 12 Pekanbaru, Riau
}

\begin{abstract}
Abstrak: Penelitian ini bertujuan untuk mencari hubungan antara pelatihan bercerita terhadap kemampuan guru dalam bercerita di Taman Kanak-kanak. Jenis penelitian yang digunakan adalah kuantitatif. Subjek pada penelitian ini adalah guru di Taman Kanak-kanak Se-Kecamatan Simpang Tiga Pekanbaru yang berjumlah 37 orang. Teknik pengumpulan data dengan cara menggunakan lembaran angket. Hasil penelitian menunjukkan $t$ hitung lebih besar dari t tabel, maka Ho ditolak, artinya ada hubungan yang signifikan antara pelatihan bercerita terhadap kemampuan guru dalam bercerita di Taman Kanak-kanak Se-Kecamatan Simpang Tiga Pekanbaru. Kemudian dalam melakukan uji reabilitas pada tiap variabel, diperoleh hasil yaitu, pada Variabel X (Pelatihan Bercerita), didapat hasil lebih besar maka semua data yang dianalisis dengan metode Alpha adalah Reliabel. Pada Variabel Y (Kemampuan Guru dalam Bercerita) didapat hasil lebih besar maka semua data yang dianalisis dengan metode Alpha adalah Reliabel.
\end{abstract}

Kata-kata Kunci: pelatihan bercerita, kemampuan guru dalam bercerita, taman kanak-kanak.

\section{CORRELATION OF STORY TELLING TRAINING WITH TEACHER'S SKILL OF SOTRY TELLING IN KINDERGARTEN}

\begin{abstract}
The purpose of this research is to discover the correlation of story telling training with the teacher's story telling skill in Kindergarten. Applying quantitative paradigm, this research used the 37 teachers of the Kindergartens in Simpang Tiga Subdistrict, Pekanbaru, as the subjects. The data were collected by distributing questionnairer. The results showed, $t$ counted was higher than $t$ table, so Ho was rejected meaning that there is a significant correlation between story telling training with the teacher's story telling skill in Kindergartens in Simpang Tiga Sub-district, Pekanbaru. Then the result of reliability test of each variable showed variable $X$ (story telling training) is higher indicating all data analyzed with Alpha method was reliable. The result for variable $Y$ (teacher's story telling skill) was higher indicating all data analyzed with Alpha method was reliable.
\end{abstract}

Keywords: story telling training, teacher's storytelling skill, kindergarten.

\section{PENDAHULUAN}

Kegiatan pelatihan guru pada dasarnya merupakan suatu bagian yang integral dari managemen dalam bidang ketenagaan di sekolah dan merupakan upaya untuk mengembangkan pengetahuan dan keterampilan guru sehingga pada gilirannya diharapkan para guru dapat memperoleh keunggulan kompetitif dan dapat memberikan pelayanan yang sebaik-baiknya. Pelatihan ini dilakukan dalam rangka memenuhi kebutuhankebutuhan guru, atau meningkatkan kemampuan guru, serta memperbaiki kekurangan-kekurangan guru dalam mengajar sehingga dengan mengikuti pelatihan guru mampu memenuhi kebutuhankebutuhannya, meningkatkan kemampuan mengajar, serta memperbaiki dari kekurangan guru dalam mengajar, dan membuat guru lebih terampil dalam mengajar serta dapat meningkatkan kinerja. Pelatihan ini dapat dilakukan oleh pihak sekolah, pihak luar sekolah, yaitu dinas-dinas terkait, lembaga-lembaga pengembangan keterampilan mengajar guru, serta organisasi-organisasi yang persatuan guru, memiliki tujuan untuk mengembangkan dan meningkatkan keahlian, kemampuan atau skill para guru dalam mengajar. Pelatihan ini dapat dimanfaatkan para guru untuk mengembangkan berbagai macam kemampuannya. Salah satunya guru mengikuti pelatihan bercerita agar dapat meningkatkan kemampuannya dalam 
bercerita. Karena pada Pendidikan Anak Usia Dini, murid sangat menyukai cerita dan dongeng. Hanya saja tidak semua guru memiliki kemampuan dalam bercerita. Banyak yang menganggap bercerita merupakan salah satu teknik kuno dalam proses pembelajaran abad modern ini. Banyak guru yang pada saat membaca cerita tidak menghayati cerita tersebut, hal ini bisa dilihat dari cara guru membaca dengan nada suara yang datar-datar saja, tidak ada intonasi maupun perubahan mimik wajah.

Guru yang sudah mengikuti pelatihan bercerita, menunjukkan banyak perubahan besar dalam kemampuannya bercerita pada anak. Guru menjadi lebih terpancing untuk lebih baik dalam bercerita, dan mengembangkan kemampuan berceritanya, serta lebih bersemangat dalam bekerja. Hal ini dikarenakan guru setelah mengikuti pelatihan bercerita, seperti mendapatkan "suntikan" semangat baru, yang merubah pola pikir yang sederhana menjadi lebih kompleks, terutama mengenai kemampuan guru dalam bercerita. Berdasarkan uraian tersebut, maka rumusan masalah yang diteliti adalah apakah terdapat pengaruh pelatihan bercerita terhadap kemampuan guru dalam bercerita di Taman Kanak-kanak SeKecamatan Simpang Tiga Pekanbaru.

Pelatihan merupakan bagian dari investasi SDM (human investment) untuk meningkatkan kemampuan dan keterampilan kerja, dan dengan demikian meningkatkan kinerja pegawai (Payaman dalam Mangkunegara, 2005). Pelatihan biasanya dilakukan dengan kurikulum yang disesuaikan dengan kebutuhan jabatan, diberikan dalam waktu yang relatif pendek, untuk membekali seseorang dengan keterampilan kerja.

Pelatihan juga diartikan sebagai usaha untuk meningkatkan kinerja pegawai dalam pekerjaannya sekarang atau dalam pekerjaan lain yang akan dijabatnya segera. Pelatihan (training) merupakan sebuah proses sistematis untuk mengubah perilaku kerja seorang/sekelompok pegawai dalam usaha meningkatkan kinerja organisasi. Pelatihan terkait dengan keterampilan dan kemampuan yang diperlukan untuk pekerjaan yang sekarang dilakukan. Pelatihan berorientasi ke masa sekarang dan membantu pegawai untuk menguasai keterampilan dan kemampuan (kompetensi) yang spesifik untuk berhasil dalam pekerjaannya (Ivancevich, 2008)

Pendapat lain mengemukakan bahwa pelatihan adalah proses mengajarkan karyawan baru atau yang ada sekarang, keterampilan dasar yang mereka butuhkan untuk menjalankan pekerjaan mereka (Dessler, 2009). Pelatihan merupakan salah satu usaha dalam meningkatkan mutu sumber daya manusia dalam dunia kerja. Karyawan, baik yang baru ataupun yang sudah bekerja perlu mengikuti pelatihan karena adanya tuntutan pekerjaan yang dapat berubah akibat perubahan lingkungan kerja, strategi, dan lain sebagainya.

Terdapat beberapa manfaat penyelenggaraan program pelatihan baik untuk sekolah maupun untuk guru. Manfaat penyelenggaraan program pelatihan untuk sekolah, antara lain: (a) meningkatkan produktivitas kerja sekolah sebagai keseluruhan, (b) terwujudnya hubungan yang serasi antara atasan dan bawahan, (c) terjadinya proses pengambilan keputusan yang lebih cepat dan tepat, (d) meningkatnya semangat kerja seluruh tenaga kerja dalam organisasi dengan komitmen organisasional yang lebih tinggi, (e) mendorong sikap keterbukaan manajemen melalui penerapan gaya manajerial yang partisipatif, (f) memperlancar jalannya komunikasi yang efektif, (g) penyelesaian konflik secara fungsional (Siagian, 2007).

Pendekatan yang sistematis dalam pelatihan meliputi empat tahap. Pertama, mengenali kebutuhan-kebutuhan. Pada tahap ini, dilakukan peninjauan pada kebutuhan-kebutuhan apa yang diinginkan. Kebutuhan-kebutuhan ini bisa saja berupa kekurangan-kekurangan guru dalam mengajar, atau hal-hal apa saja yang ingin dikembangkan guru sebagai keahlian atau skill. Kedua, merencanakan untuk memenuhi kebutuhan-kebutuhan. Kemudian setelah mengenali kebutuhan-kebutuhan tersebut, maka, direncanakanlah hal-hal untuk memenuhi kebutuhan tersebut. Merancang cara apa yang akan dilakukan, agar kebutuhan-kebutuhan tersebut terpenuhi. Ketiga, pelaksanaan.Setelah membuat rancangan, maka rancangan tersebut direalisasikan dalam wujud nyata. Dari kebutuhan yang ingin kita penuhi, maka dirancanglah sebuah kegiatan yang kemudian dilaksanakan sebagai upaya pemenuhan kebutuhan. Keempat, evaluasi. Setelah melaksanakan pemenuuhan kebutuhan, dilakukan evaluasi. Menilai apakah pelaksanaan tersebut mampu memenuhi kebutuhan yang diinginkan. Serta melihat apakah pelaksanaan itu bisa berjalan sesuai yang diinginkan atau tidak (Cowling, 2002: 112).

Selanjutnya, cerita merupakan salah satu bentuk sastra yang memiliki keindahan dan 
kenikmatan tersendiri. Akan menyenangkan bagi anak-anak maupun orang dewasa, jika pengarang, pendongeng, dan penyimaknya sama-sama baik. Cerita adalah salah satu bentuk sastra yang bisa dibaca atau hanya didengar oleh orang yang tidak bisa membaca. Metode bercerita adalah salah satu cara menyampaikan informasi dalam proses pembelajaran, khususnya pada anak usia dini (Nurbiana, 2007). Di Taman Kanak-kanak metode bercerita adalah salah satu metode pengembangan bahasa yang dapat mengembangkan beberapa aspek fisik maupun psikis anak usia dini sesuai dengan perkembangannya.

Metode bercerita merupakan salah satu pemberian pengalaman belajar bagi anak TK dengan membawakan cerita kepada anak secara lisan (Moeslichatoen, 2004). Cerita yang dibawakan guru harus menarik, dan mengundang perhatian anak dan tidak lepas dari tujuan pendidikan bagi anak TK. Pendapat lain mengungkapkan bahwa bercerita adalah metode yang sangat baik dalam pendidikan (Latif, 2012). Pada umumnya, cerita disukai oleh jiwa manusia karena memiliki pengaruh yang menakjubkan untuk dapat menarik perhatian pendengar dan membuat seseorang bisa mengingat kejadian-kejadian dalam sebuah kisah dengan cepat.

Beberapa manfaat dan tujuan bercerita, adalah sebagai berikut: (a) dapat menanamkan nilainilai kejujuran, keberanian, kesetiaan, keramahan, ketulusan, dan sikap-sikap positif lain dalam kehidupan anak pada lingkungan keluarga, sekolah, dan luar sekolah; (b) memberikan pengetahuan sosial, nilai-nilai moral dan keagamaan pada anak; (c) melatih anak dalam mendengarkan; (d) mengembangkan kemampuan kognitif, afektif, maupun psikomotor anak; (e) serta mampu mengembangkan daya imajinatif anak (Moeslichatoen, 2004).
Bercerita juga bertujuan memberi pengalaman belajar agar anak memperoleh penguasaan isi cerita yang disampaikan lebih baik. Melalui bercerita anak menyerap pesan-pesan yang diturkan melalui kegiatan bercerita. Penuturan cerita yang sarat informasi atau nilai-nilai itu dihayati anak dan ditetapkan dalam kehidupan sehari-hari.

Beberapa teknik-teknik yang dilakukan dalam bercerita adalah sebagai berikut. Pertama, posisi atau tempat ketika bercerita. Bercerita harus di tempat yang tepat sehingga semua audiens dapat melihat dengan jelas. Tempat yang tepat disesuaikan dengan kondisi acara, termasuk penempatan audiensnya. Kedua, suara harus lantang dan jelas (tidak perlu berteriak) agar dapat didengar oleh semua anak atau audiens lainnya dengan jelas. Ketiga, penguasaan materi cerita. Untuk menyajikan cerita yang baik, maka harus betul-betul menguasai materi cerita sehingga tahu kapan harus menekankan kata-kata tertentu atau memperlihatkan mimik muka tertentu. Keempat, penjiwaan. Kelima, mengetahui kapan saatnya memperbesar atau memperkecil suara harus dapat menjiwai isi ceritanya sehingga jika itu tercapai, maka mudah sekali menirukan suara-suara tertentu. Keenam, gerakan. Dalam bercerita, tubuh dan anggota tubuh juga bergerak agar cerita menjadi menarik. Tunjukkan gerakan yang sesuai dengan cerita (Latif, 2012). Selain itu, ada beberapa langkah yang bisa dilakukan oleh guru pada saat bercerita, yaitu: (a) memilih cerita, (b) persiapan sebelum masuk kelas, dan (c) perhatikan posisi duduk anak (Majid, 2008).

Berkenaan dengan masalah yang diteliti, maka dirumuskan hipotesis penelitiannya adalah terdapat Pengaruh pelatihan bercerita terhadap kemampuan guru dalam bercerita di Taman Kanakkanak Se-Kecamatan Simpang Tiga Pekanbaru.

\section{METODE PENELITIAN}

Metode penelitian yang akan digunakan adalah metode kuantitatif. Penelitian dilakukan di Taman Kanak-kanak Se-Kecamatan Simpang Tiga Pekanbaru pada bulan Februari hingga Maret 2016. Populasi dalam penelitian ini sebanyak 105 orang guru, sedangkan yang dijadikan sampel adalah bagian dari jumlah dan karakteristik yang dimiliki oleh populasi tersebut yaitu sebanyak 37 orang guru. Adapun teknik pengumpulan data yang dipergunakan dalam penelitian ini adalah dengan cara menggunakan angket yang bertujuan untuk memperoleh data mengenai Hubungan Pelatihan Bercerita terhadap Kemampuan Guru dalam Bercerita di Taman Kanak-kanak Se-Kecamatan Simpang Tiga Pekanbaru. Analisis data bersifat kuantitatif/ statistik dengan tujuan untuk menguji hipotesis yang telah ditetapkan (Sugiyono, 2010). 


\section{HASIL DAN PEMBAHASAN}

\section{Hasil Penelitian}

Dari variabel pelatihan bercerita memberikan kontribusi terhadap kemampuan guru dalam bercerita di Taman Kanak-kanak Se-Kecamatan Simpang Tiga Pekanbaru sebesar $45,4 \%$ dan sisanya $54,6 \%$ ditentukan oleh variabel lain. Jadi pelatihan bercerita yang diikuti oleh guru, mampu mempengaruhi kemampuan guru dalam bercerita. Selebihnya kemampuan guru dalam bercerita dipengaruhi oleh, pengalaman, bakat, kreativitas serta keaktifan guru dalam mencari informasi baik dari media cetak, media elektronik, maupun internet dalam meningkatkan kemampuan guru dalam bercerita pada anak selama proses pembelajaran di sekolah.

Hasil penelitian menunjukkan $\mathrm{t}$ hitung lebih besar dari t tabel, atau 4,97 >1,697, maka Ho ditolak, artinya ada hubungan yang signifikan antara pelatihan bercerita terhadap kemampuan guru dalam bercerita di Taman Kanak-kanak SeKecamatan Simpang Tiga Pekanbaru. Pengaruh pelatihan bercerita terhadap kemampuan guru dalam bercerita ini tergolong kuat, artinya pelatihan bercerita mendukung kompetensi (kemampuan) guru dalam bercerita di Taman Kanak-kanak seKecamatan Simpang Tiga Pekanbaru. Pelatihan bercerita yang diikuti oleh guru merubah cara pandang atau pola pikir guru dalam bercerita. Memberi masukan yang positif bagaimana cara yang baik bagi guru pada saat bercerita pada anak, sehingga dapat menarik minat anak mendengarkan cerita guru, bahkan dapat membuat anak larut dalam cerita yang dibacakan oleh guru.

\section{Pembahasan}

Setelah melakukan penelitian langsung di lapangan, berdasarkan judul penelitian yaitu, hubungan pelatihan bercerita terhadap kemampuan guru dalam bercerita di Taman Kanak-kanak SeKecamatan Simpang Tiga Pekanbaru, didapatkanlah hasil bahwa, ternyata t hitung lebih besar dari t tabel, atau 4,97 >1,697, maka Ho ditolak, artinya ada hubungan yang signifikan antara pelatihan bercerita terhadap kemampuan guru dalam bercerita di Taman Kanak-kanak Se-Kecamatan Simpang Tiga Pekanbaru.

Kemudian dalam melakukan uji reabilitas pada tiap variabel, diperoleh hasil yaitu, pada Variabel X (Pelatihan Bercerita), didapat hasil lebih besar dari maka semua data yang dianalisis dengan metode Alpha adalah Reliabel. Pada Variabel $Y$ (Kemampuan Guru dalam Bercerita) didapat hasil lebih besar dari maka semua data yang dianalisis dengan metode Alpha adalah Reliabel.

Dengan seringnya guru mengikuti pelatihan bercerita, dapat meningkatkan kemampuan guru dalam bercerita. Hal ini pun ditegaskan oleh Soetjipto (2007: 230), mengatakan peningkatan kemampuan guru dalam bercerita ini akan lebih berhasil apabila dilakukan oleh guru dengan kemampuan dan usaha mereka sendiri. Pelatihan memberikan bantuan kepada guru dalam merencanakan dan melaksanakan peningkatan profesional mereka dengan memanfaatkan sumber yang tersedia.

Dalam meningkatkan kemampuan guru dalam bercerita, dapat diikut sertakan pada pelatihan-pelatihan yang menunjang pengembangan kemampuan tersebut. Pelatihan itu bisa dilaksanakan oleh sekolah itu sendiri, atau bisa juga mengikut sertakan guru pada pelatihan-pelatihan yang dilaksanakan oleh instansi terkait, yayasan-yayasan yang bergerak di bidang pendidikan, atau oleh sekolah-sekolah yang mengadakan pelatihan yang berkaitan dengan pengembangan kemampuan guru dalam bercerita.

Setelah mengikuti pelatihan bercerita, guru dapat merasakan manfaat dari pelatihan tersebut, yaitu guru menjadi lebih kreatif dalam membuat cerita yang akan diceritakan pada anak, guru lebih bervariasi dalam memilih media yang digunakan dalam bercerita, guru juga sudah bisa menerapkan penggunaan intonasi sesuai dengan tokoh yang diceritakannya dalam bercerita, yang bisa menimbulkan minat anak dalam mendengarkan cerita yang dibacakan oleh guru.

\section{PENUTUP}

\section{Keseimpulan}

Berdasarkan penelitian yang telah dilakukan serta melalui proses analisa data, maka dapat disimpulkan, pengaruh pelatihan bercerita terhadap kemampuan guru dalam bercerita di Taman
Kanak-kanak Se-Kecamatan Bukitraya Pekanbaru, didapatkanlah hasil bahwa, ternyata $t$ hitung lebih besar dari t tabel, atau 4,97 > 1,697, maka Ho ditolak, artinya ada pengaruh yang signifikan antara pelatihan bercerita terhadap kemampuan guru dalam bercerita 
di Taman Kanak-kanak Se-Kecamatan Simpang Tiga Pekanbaru.

Kemudian dalam melakukan uji reabilitas pada tiap variabel, diperoleh hasil yaitu, pada variabel $X$ (Pelatihan Bercerita), didapat hasil lebih besar dari maka semua data yang dianalisis dengan metode Alpha adalah reliabel. Pada variabel Y (Kemampuan Guru dalam Bercerita) didapat hasil lebih besar dari maka semua data yang dianalisis dengan metode Alpha adalah Reliabel.

\section{Saran}

Berdasarkan hasil penelitian dan analisis data yang telah dilaksanakan oleh peneliti dengan menitikberatkan kepada pengaruh pelatihan bercerita terhadap kemampuan guru dalam bercerita di taman kanak-kanak se-Kecamatan Bukitraya Pekanbaru, maka peneliti menyampaikan beberapa saran sebagai berikut. Pertama, untuk kepala sekolah agar dapat lebih sering mengikutsertakan guru dalam pelatihan-pelatihan bercerita yang diadakan baik oleh dinas pendidikan maupun oleh pihak swasta yang mampu mendukung kemampuan guru dalam bercerita. Kedua, untuk guru agar bisa memanfaatkan ilmu yang diperolehnya saat mengikuti pelatihan bercerita dan di gunakan dalam meningkatkan kemampuannya dalam bercerita di dalam kelas. Ketiga, peneliti selanjutnya agar dapat meneruskan penelitian tentang hubungan pelatihan bercerita terhadap kemampuan guru dalam bercerita di taman kanak-kanak dengan lebih efektif dan optimal.

\section{DAFTAR PUSTAKA}

Akdon. (2005). Aplikasi statistika dan metode penelitian untuk administrasi \& manajemen. Bandung: Dewa Ruchi.

Cowling, A. (2002). The essence of personnel management an industrial relation (terjemahan). Yogyakarta: ANDI.

Dessler, G. (2009). Manajemen sumber daya manusia. Jakarta: Index.

Ivancevich, J. (2008). Perilaku dan manajemen organisasi. Jakarta: Erlangga.

Latif, M. A. (2012). The miracle of story telling. Jakarta: Zikrul.

Majid, A. A. A. (2008). Mendidik dengan cerita. Bandung: Rosdakarya.

Mangkunegara, A. P. (2005). Evaluasi kinerja sdm. Bandung: Refika Aditama.
Mathis, R.L.,\& Jackson, J. H. (2002). Manajemen sumber daya manusia. Jakarta: Salemba Empat.

Moeslichatoen. (2004). Metode pengajaran di taman kanak-kanak. Jakarta: Rineka Cipta.

Nurbiana, D. (2007). Metode pengembangan bahasa. Jakarta : Universitas Terbuka.

Siagian, S. (2007). Manajemen sumber daya manusia. Jakarta: Bumi Aksara.

Sudijono, A. (2004). Pengantar statistik pendidikan. Jakarta: Rajawali Pers.

Soetjipto. (2007). Profesi keguruan. Jakarta: Rineka Cipta.

Sugiyono. (2010). Metode penelitian pendidikan. Bandung: Alfabeta. 